\title{
STUDENT READINESS AND CHALLENGE IN COMPLETING HIGHER ORDER THINKING SKILL TEST TYPE FOR MATHEMATICS
}

\author{
Kusaeri*1 $^{1}$, Asep Saepul Hamdani ${ }^{2}$, Suprananto ${ }^{3}$ \\ ${ }^{1,2}$ Universitas Islam Negeri Sunan Ampel Surabaya \\ ${ }^{3}$ Balitbang Kementerian Pendidikan dan Kebudayaan Republik Indonesia
}

\begin{tabular}{l} 
Article Info \\
\hline Article history: \\
Received Jan 21, 2019 \\
Revised Feb 13, 2019 \\
Accepted Feb 28, 2019 \\
\hline
\end{tabular}

\section{Keywords:}

Mathematics

HOTs

Student readiness

Student challenge

\begin{abstract}
Mathematics teaching and learning should equip students with the ability to think critically and creatively and problem-solving skill to enable them to compete in the industrial revolution 4.0. This descriptive explorative study explores the readiness and challenges faced by Indonesian junior high school (SMP/MTs) student in solving HOTs type mathematics test using Islamic context. Data were collected from a test-based open-ended questionnaire distributed to 164 students in the 8th of five schools in Sidoarjo East Java comprising 2 junior madrasas (Islamic schools), 2 Islamic-based junior high schools and 1 public junior high school. Descriptive analysis using SPSS and categorization of responses (referring to response options in the questionnaire such as have ever-never, necessary-unnecessary, answered-not answered, etc) show that considering their experience, the students are "less ready" to face HOTs type mathematics test. However, students expect that they can be given more practices in doing HOTs type mathematics questions to help them get accustomed to this type of question. Being unaccustomed to nonroutine and lengthy questions, lazy trait and being unfamiliar to Islamic terms used as the context of the question becomes the challenges for the students in facing HOTs type mathematics test.
\end{abstract}

Copyright @ 2019 IKIP Siliwangi. All rights reserved.

\section{Corresponding Author:}

Kusaeri,

Departement of Mathematics Education,

Universitas Islam Negeri Sunan Ampel Surabaya,

Jl. Jl. Ahmad Yani No.117, Surabaya, Jawa Timur, Indonesia.

Email: kusaeri@uinsby.ac.id

\section{How to Cite:}

Kusaeri, K., Hamdani, A. S., \& Suprananto, S. (2019). Student readiness and challenge in completing higher order thinking skill test type for mathematics. Infinity, 8(1), 75-86.

\section{INTRODUCTION}

Implementation of Higher Order Thinking Skill (HOTs) test type for mathematics in the Indonesian National Exam 2018 has invited various responses from test takers and has become viral in social media. Test takers consider that the HOTs type mathematics test is too difficult. In fact, the questions in the test are not as complex as what the students have complained. It is just a matter of student not being accustomed to such type of question.

This phenomenon of student being not accustomed to HOTs type question may be rooted from the learning trait and culture at school that has not offered students much to be 
accustomed to HOTs. In consequence, students are not used to dealing and completing questions or problems in mathematics that require HOTs (Kusaeri, Sadieda, Indayati \& Faizien, 2018; Nursyahidah \& Albab, 2017). So far, most mathematics problems provided by mathematics teachers are related to the ability to apply mathematics formulas, procedures or algorithms (Dewantara, Zulkardi \& Darmawijoyo, 2015; Kusaeri \& Aditomo, 2019; Sembiring, Hadi \& Dolk, 2008). There have not been sufficient mathematics problems that lead and motivate students to hone their analytical, evaluative and creative skills.

Student unfamiliarity in dealing with and completing HOTs type of test make it difficult for the student to find correct answer to HOTs type mathematics questions. This condition can bring two possible consequences. First, students with high level of curiosity will find HOTs type mathematics test as a challenge. Once they can solve a HOTs mathematics problem, they will be excited and motivated to complete other HOTs questions. In this perspective, HOTs question can successfully trigger student interest. On the other hand, students having low interest in mathematics may feel desperate when they have to complete HOTs mathematics questions. They will tend to choose mathematics questions they commonly face; thus, they are not used to solving HOTs mathematics questions (Kamarullah, 2017).

Student low skill in completing HOTs type of test does not only happen in Indonesia. Studies conducted in Nigeria (Adeyami, 2012), United States (Marin \& Halpern, 2011) and Dubai (Taleb \& Chadwick, 2016) have shown similar findings. Such low skill seems to be triggered by student deficiency in identifying information provided in question item, in interpreting and sorting information in the question item, implementing strategy to find answer to the question, connecting inter-related concepts, and using reasoning to solve complex HOTs type test questions (Suryapuspitarini, Wardono, Kartono, 2018). In general, student weakness in completing HOTs type test is due to student lack of competence to generalize some information in the test item in order to design new strategies to solve the problems.

Findings from some previous studies on student weaknesses in solving HOTs type test have been congruous. Abdullah, Abidin, \& Ali (2015) found that student difficulties in solving HOTs type test lie in ability to connect information and find solution to the problem. Finding by Gais \& Afriansyah (2017) shows that lack of meticulousness at the process of finishing the task, low mathematics skill, less optimal learning process, and lack of parental monitoring have been indicated to cause student difficulties in solving HOTs type test. A research by Hadi et al. (2018) also finds that student unfamiliarity with HOTs type test, student low interest in tackling HOTs problems and student indifference toward lengthy question bring student difficulty in completing HOTs type test.

The aforementioned previous studies have extensively explored student difficulties in completing HOTs type mathematics test but have not investigated the extent to which student can do HOTs mathematics test when the question items incorporate context they are familiar with In Indonesia, such context can be that of Islamic context for students in Islamic school or madrasa. This is because these two institutions have more Islamic subjects than public school; hence, the students in Islamic school or madrasa have been familiar with Islamic context. Thus, the integration of Islamic context to HOTs type mathematics test may facilitate student familiarity with the context and promote student interest to the questions. The integration referred here is the use of real life context (fiqh and ibadah) in the mathematics problem presented to the students.

In the context of Indonesian madrasa and Islamic school, research by Kurniati (2015) and Kusaeri, Sadieda, Indayati \& Faizien (2018) find that the integration of Islamic context to HOTs type mathematics test has made mathematics more interesting subject 
because student feels that mathematics has become part of life and its diversity. It can also bring new perspective to the student that it is not hard to relate mathematics to Islamic context. The integration of mathematics and Islamic context can develop student reasoning in order to build critical awareness about the ultimate truth based on Islamic value and learning.

As integration of specific context to HOTs type mathematics test has not yet gained particular attention in the existing theories and previous studies, research that explores student readiness and challenge in solving HOTs type mathematics test is deemed to be important. In Indonesian context, studies about madrasa and Islamic school students, particularly those that are related to their ability to complete HOTs type mathematics questions have not received much attention. This research aims to identify madrasa tsanawiyah (Islamic junior high) and Islamic school student readiness and challenge in completing HOTs type mathematics test that integrates Islamic context.Hence, the questions in this research are: (a) how is the readiness of students (madrasah tsanawiyah, Islamic school and general junior high school) to solve HOTs type omathematics problems that integrate Islamic context? and (b) what are the challenges faced by students in solving HOTs type mathematics problems that integrate Islamic context?.

\section{METHOD}

This research is descriptive explorative in that it explores the students readiness and challenges in solving HOTs type mathematics problems. The results of such an exploration are then described in tables of frequency distribution and percentages.

Data were collected through test-based open-ended questionnaire, that is a inquiry technique in which participants filled out a questionnaire after taking HOTs type mathematics test that integrates Islamic context. This data inquiry technique has enabled collection of rich and varied data as students were given freedom to respond and express their ideas. So, student readiness and difficulties in completing HOTs type mathematics test can be better portrayed.

\subsection{Participants}

The participants of this research are 164 students in the 8th grade of 5 junior high school (SMP/ MTs) spread in Sidoarjo, East Java selected based on the representation of educational institutions' type, primarily affiliated to Islamic school. These five schools /madrasa are SMP Al-Muslim Sidoarjo, SMP Progressive Bumi Sholawat Sidoarjo, MTsN 1 Sidoarjo, MTsN Tlasih Sidoarjo and SMPN 5 Sidoarjo, each is represented by one class as participants based on their headmaster consideration. The five selected schools are considered to be representative of excellent schools (madrasah, Islamic school and general school) in Sidoarjo district. The participants are nearly balanced between the male students (46.34\%) and female students (53.66\%). Data were collected in mid of the second semester of academic year 2018/2019.

\subsection{Instrument}

Test-based open-ended questionnaire was utilized to measure student readiness and challenge in completing HOTs type mathematics test. Two questions aim to explore student readiness are formulated as "How often do you get HOTs type mathematics test? Please elaborate your answer!" and "Do you feel the need to be trained in solving HOTs type mathematics test?" Two questions are also asked to explore challenge faced by students: "Is it more difficult to complete HOTS questions that integrate Islamic context?" 
and "What challenges you experience in solving HOTs type mathematics test with Islamic context?"

To strengthen the result of both data types from the questionnaire, eight (8) twotier multiple choice test using Islamic context (fiqh and prayer) was used. The test was also completed with reasoning. Level one of the test contains questions with four (4) possible answers, while the second level contains reasons which must be filled by students in reference to their corresponding answer choice. By this method, student readiness, challenge and understanding (either complete or incomplete) to HOTs type mathematics test can be investigated (Treagust, 2006).

The piloting of the test items show that the items have distinguishing factors (a) difficulty level of questions (b) and guessing factor (c) as follow: $0.55<\mathrm{a}<1.16 ; 0.00<\mathrm{b}$ $<1.40$; and $0.16<c<0.29$. Referring to Baker (2001), these eight items are in the category of good item.

\subsection{Analysis}

Student readiness and challenge collected through questionnaire were analyzed descriptively using SPSS. Similar response pattern were grouped into one category. The two-tier multiple-choice data were analyzed by these following steps: (a) recording/summarizing results of multiple-choice tests with reasoning from all students, and (b) constructing and classifying the reasoning answered by students as a second tier choice.

\section{RESULTS AND DISCUSSION}

This section is organized into 2 (two) sub-sections: (a) student readiness in completing HOTs type mathematics test, and (b) student chalenge in completing HOTs type mathematics test.

\subsection{Student readiness in facing HOTS type mathematics test}

Data from the questionnaire presented in Table 1 indicate that the majority of students $(63.1 \%)$ stated that they had never received HOTs type mathematics test at school. This indicates that teachers do not generally give exercises or mathematics tests that require higher-level thinking. In fact, if teachers provide more varieties of this type of test/question, the students will have better ability to explore their reasoning when they face a variety of other questions. They will also used to honing their ability to understand, analyze problems, create a math model, and find solution/answer.

Table 1. Student Readiness to Solve HOTS Type Mathematics Test

\begin{tabular}{llcc}
\hline $\begin{array}{c}\text { Aspects of student's } \\
\text { learning readiness }\end{array}$ & \multicolumn{1}{c}{ Responses } & $\begin{array}{c}\text { Number of } \\
\text { Respondents }\end{array}$ & Percentage \\
\hline $\begin{array}{l}\text { How often do you get } \\
\begin{array}{l}\text { HOTs type } \\
\text { mathematics test? }\end{array}\end{array}$ & Have Ever: & 61 & $36.9 \%$ \\
$\begin{array}{l}\text { Please elaborate your } \\
\text { answer. }\end{array}$ & Twice & 26 & $15.8 \%$ \\
& Sometimes & 9 & $5.3 \%$ \\
& $\begin{array}{l}\text { At the mathematics } \\
\text { Olympics } \\
\text { Never }\end{array}$ & 20 & $12.3 \%$ \\
& & 103 & $3.5 \%$ \\
\hline
\end{tabular}


Infinity Volume 8, No 1, February 2019, pp. 75-86 79

\begin{tabular}{|c|c|c|c|}
\hline $\begin{array}{l}\text { Aspects of student's } \\
\text { learning readiness }\end{array}$ & Responses & $\begin{array}{l}\text { Number of } \\
\text { Respondents }\end{array}$ & Percentage \\
\hline \multirow{10}{*}{$\begin{array}{l}\text { Do you feel the need } \\
\text { to be trained in solving } \\
\text { HOTs type } \\
\text { mathematics test? }\end{array}$} & Necessary/needed: & 138 & $84.2 \%$ \\
\hline & $\begin{array}{l}\text { Training high-level } \\
\text { thinking skills }\end{array}$ & 43 & $26.3 \%$ \\
\hline & $\begin{array}{l}\text { Requiring particular } \\
\text { understanding }\end{array}$ & 37 & $22.8 \%$ \\
\hline & $\begin{array}{l}\text { Preparing for a } \\
\text { mathematics test in } \\
\text { national exam }\end{array}$ & 12 & $7 \%$ \\
\hline & $\begin{array}{l}\text { Presenting exciting } \\
\text { and challenging } \\
\text { problem }\end{array}$ & 14 & $8.8 \%$ \\
\hline & $\begin{array}{l}\text { Preparing questions to } \\
\text { face the next HOTs } \\
\text { type of test }\end{array}$ & 32 & $19.3 \%$ \\
\hline & $\begin{array}{l}\text { Unnecessary/not } \\
\text { needed: }\end{array}$ & 26 & $15.8 \%$ \\
\hline & $\begin{array}{l}\text { Dividing focus on } \\
\text { other subjects }\end{array}$ & 9 & $5.3 \%$ \\
\hline & $\begin{array}{l}\text { Adding burden of } \\
\text { thought }\end{array}$ & 12 & $7 \%$ \\
\hline & $\begin{array}{l}\text { Being not needed at } \\
\text { national exam }\end{array}$ & 5 & $3.1 \%$ \\
\hline
\end{tabular}

In contrast, students who lack experience in dealing with HOTs type mathematics test will find it difficult because they do not know enough patterns or steps needed to solve the problem/question. Evidently, students who answered 'never' in facing HOTS type mathematics test, based on the answer of multiple choice with reasoning questions, were not yet able to solve questions optimally.

However, there is an interesting fact and worth highlighting that students from public junior were in fact gave better results than junior students from Islamic school or madrasa (MTs). A good indicator can be seen from their more coherent thinking process starting from analyzing problems, making mathematics model and solving problem. This is different from students from MTs who mostly have not been able to solve problems in coherent steps and to find the correct answer. A similar case was found from junior high students in Islamic school who prefer to answer randomly without calculating or analyzing the question first.

This fact is interesting to observe as students from public junior high also feel they have not been familiar with HOTs mathematics test in Islamic context, but in fact they can still perform well. It is certainly influenced by the learning process that occurs in public junior high which is more conducive in giving mathematics problems that demand high reasoning (Kusaeri, Aditomo, Ridho \& Fuad, 2018). So they are more familiar with tests or questions that require reasoning skills. Student familiarity to questions that require higherlevel thinking, according to Lee \& Francis (2018), can make the student ready to solve various forms of mathematics problem.

Despite the surprising results above, students have expectations to be trained to be able to tackle HOTs type mathematics test. This is indicated by the larger percentage of respondents who expressed 'necessary/needed' much larger $(84.2 \%)$ compared to 'unnecessary/not needed' (see Table 1). They state that by training of dealing with HOTs 
type mathematics test will improve their thinking skill. The presumption evoked from their uncertainty in solving HOTs questions given at the beginning of the research.

In addition to the above reason, some of them also acknowledged that solving HOTs type mathematics test require certain skills, certain comprehension, even a specific strategy (Nadapdap \& Istiyono, 2017). Thus, they think it is necessary to have a particular training in order to deal with and solve HOTs type mathematics test. Preparation for the National Examination (UN) is also another reason considered by students, hence they are ready to be trained in dealing with HOTs type mathematics test. In this way, they hope that they can successfully get optimal UN mathematics score.

Another factors contributing to the students need to get training is because they really enjoy the questions presented. Some students become interested to learn HOTs mathematics. Further exploration of the data also show that students who like challenge and problem complexity are more willing to participate in training.

Students who assume such training as 'not needed/unnecessary' (Table 1) view that mathematics is a difficult subject to understand. Not surprisingly, 7\% of students expressed that training was not necessary because it will add burden to their minds. Regular and routine mathematics question they encounter are considered to be difficult already. The one that integrates the Islamic context is considered to give them more burden. This is because such question will involve all levels of thinking from Bloom's Taxonomy (Kusaeri, 2014).

It can be concluded from the above data that student readiness in dealing with HOTs type mathematics test is low when it is referred to student experience. However, they have very good readiness in dealing with HOTs type mathematics test when viewed from the side of willingness to accept training.

\subsection{Student Challenges in Facing HOTs Type Mathematics Test}

The results of the two-tier multiple-choice with reasoning test analysis, portray challenge faced by students when solving HOTs type mathematics test. The analysis was based on the number of students who answered and who did not answer each item. Then, the answers were categorized and put into percentages based on the correct and incorrect answers. Table 2 presents the result of analysis.

Table 2. Analysis of Student Answer of Multiple Choice with Reasoning Test

\begin{tabular}{clcc}
\hline Problem No & $\begin{array}{c}\text { Answer Sheet Analysis } \\
\text { Results }\end{array}$ & Frequency & Percentage \\
\hline 1 & Answered: & 73 & $44.5 \%$ \\
& True & 25 & $15.2 \%$ \\
& False & 48 & $29.3 \%$ \\
& Not Answered & 91 & $55.5 \%$ \\
& & & \\
& Answered: & 113 & $68.9 \%$ \\
& True & 78 & $47.6 \%$ \\
& False & 35 & $21.3 \%$ \\
& Not Answered & 51 & $31.1 \%$ \\
& Answered: & 130 & $79.3 \%$ \\
& True & 51 & $31.1 \%$ \\
& False & 79 & $48.2 \%$ \\
& Not Answered & 34 & $20.7 \%$
\end{tabular}




\begin{tabular}{clcc}
\hline Problem No & \multicolumn{1}{c}{$\begin{array}{c}\text { Answer Sheet Analysis } \\
\text { Results }\end{array}$} & Frequency & Percentage \\
\hline 4 & Answered: & 47 & $28.7 \%$ \\
& True & 13 & $7.9 \%$ \\
& False & 34 & $20.7 \%$ \\
& Not Answered & 117 & $71.3 \%$ \\
& Answered: & 128 & $78.0 \%$ \\
& True & 32 & $19.5 \%$ \\
& False & 96 & $58.5 \%$ \\
& Not Answered & 36 & $22.7 \%$ \\
& Answered: & & $65.9 \%$ \\
& True & 108 & $10.4 \%$ \\
& False & 17 & $55.5 \%$ \\
& Not Answered & 91 & $34.1 \%$ \\
& Answered: & 56 & $28.1 \%$ \\
& True & 46 & $8.5 \%$ \\
& False & 14 & $19.6 \%$ \\
& Not Answered & 32 & $71.9 \%$ \\
& Answered: & 118 & $31.1 \%$ \\
& True & 51 & $11.0 \%$ \\
& False & 18 & $20.1 \%$ \\
& Not Answered & 33 & $68.9 \%$ \\
\hline
\end{tabular}

Table 2 informs that number 2, 3, 5 and 6 relatively get more answers from the students although the answers tend to be incorrect. Error occurs because students were in a hurry concluding problem given. They assumed those questions were easy; thus, they tended to be sloppy and less focus on what the question actually implies.

For theother four question items (number 1, 4, 7 and 8), many students tend notto answer. The context or long narration can be suspected to be their triggers. The students seemed to be not familiar with problems that have long narration. Long narration requires in-depth understanding and this can makes students find it difficult to comprehend (Laily, 2014). When students face difficulty in understanding questions, consequently the mathematics models they present to explain each sentences or steps can also be wrong (Samritin \& Suryanto, 2016). Questions with long narration tend to frustrate students and make them demotivated to complete the questions.

Table 2 also identifies that students also tend to avoid questions that displays image element, such as numbers 1 and 8 . This kind of question, not only requires students to do calculations in order to find a solution, but also to understand the image. If students cannot understand the image presented, they will also find it difficult to answer. This lack of understanding makes it difficult for the students to associate their imagination to what is referred in the question and the image (Bokosmaty et al., 2015).

Some questions were unanswered because of various factors. Among others is because the material presented in the question is complex. This finding confirms finding by Abdullah et al. (2015) in that students find it difficult when the questions are different from what they normally encounter. It is possible that students have forgotten the material or the various procedures that are commonly used to solve such type of problems. In the end, 
they will ignore this type of questions and choose other questions that are easier to complete.

Table 3 further shows various difficulties experienced by students when solving HOTsmathematics problems. The data show that most students $(31.6 \%)$ stated that the given HOTs mathematics problem makes them dizzy and feel confused how to complete.

Table 3. Student Challenge Based on Questionnaire Results

\begin{tabular}{|c|c|c|c|}
\hline Aspect of Constraints & Responses & $\begin{array}{c}\text { Number of } \\
\text { Respondents }\end{array}$ & Percentage \\
\hline \multirow{8}{*}{$\begin{array}{l}\text { Is it more difficult to } \\
\text { complete HOTS } \\
\text { questions that integrate } \\
\text { Islamic context? }\end{array}$} & Agree: & 95 & $57.9 \%$ \\
\hline & $\begin{array}{l}\text { Increasingly create confusion } \\
\text { to complete. }\end{array}$ & 52 & $31.6 \%$ \\
\hline & $\begin{array}{l}\text { Spending lengthy time to } \\
\text { complete. }\end{array}$ & 11 & $7.0 \%$ \\
\hline & $\begin{array}{l}\text { More difficult because there } \\
\text { is too much information on } \\
\text { the questions }\end{array}$ & 14 & $8.8 \%$ \\
\hline & $\begin{array}{l}\text { Not easy to connect some } \\
\text { information in the problem }\end{array}$ & 18 & $10.5 \%$ \\
\hline & Disagree: & 69 & $42.1 \%$ \\
\hline & $\begin{array}{l}\text { Mathematics seems to be } \\
\text { closer to everyday life and I } \\
\text { learn more about Islam. }\end{array}$ & 46 & $28.1 \%$ \\
\hline & $\begin{array}{l}\text { Enjoy solving the problem } \\
\text { more. }\end{array}$ & 23 & $14.0 \%$ \\
\hline \multirow{5}{*}{$\begin{array}{l}\text { What challenges do you } \\
\text { experience in solving } \\
\text { HOTs type mathematics } \\
\text { test with Islamic } \\
\text { context? }\end{array}$} & The test is less familiar & 92 & $56.1 \%$ \\
\hline & The narration is too long & 38 & $23.2 \%$ \\
\hline & $\begin{array}{l}\text { The time to work on is too } \\
\text { tight }\end{array}$ & 12 & $7.31 \%$ \\
\hline & I am lazy & 7 & $4.27 \%$ \\
\hline & The termsusedrelated to & 15 & $9.15 \%$ \\
\hline
\end{tabular}

when solving mathematics routine questions, felt more troubled when doing mathematics HOTs test. The context of Islam used make them think twice, namely thinking about the mathematics models and Islamic values contained in the question. In the end, the confusion covers the meaning and purpose HOTS mathematics problems that are basically used to improve students reasoning skills (Dorr, 2017).

In addition to creating confusion, research data shows that HOTs mathematics questions also make it difficult for the students to connect some of information the questions. This type of questions has different characteristics with routine questions that the students usually encounter. No wonder that they feel they need to go through different process. This kind of problem requires the students to be able to analyze problems, explore previous experiences, dig up the materials that have been obtained, to be creative and put a lot of effort (Kurniati, Harimukti\& Jamil, 2016). Therefore, it is not easy to draw on a wide range of capabilities above to analyze relationship between components in question.

Despite the above drawbacks of HOTs type mathematics test with Islamic context integration, there is still a positive element of this type of test. The integration of Islamic 
values in the mathematics test can bring new perspective to the students. The students who previously thought negatively towards mathematics and perceived that it is hard associate mathematics to everyday life, even in the context of Islam, can now get a new insight on the possible relationship between mathematics and Islamic values.

For the majority of students who come from MTs and Islamic junior high and do not like mathematics, this can be a breakthrough in the reference about kind of test they get. Those who initially did not like mathematics may shifts slightly and can like mathematics more. The impact may be felt indirectly. The students are increasingly able to do mathematics questions because there are links with Islamic values. This can change theirparadigm about mathematics and become an appeal forthem to constantly interact with mathematics.

These types of problems are not normally met by students and are not monotonous. Therefore, this may bring euphoria to the students; they feel the complex thinking in finding solutions to the question. Such euphoria makes students enjoy the questions presented and encourage them to continue to complete other question (Muis et al., 2015).

Table 3 also shows that difficulties experienced by most of the students are because they are not accustomed to face this kind of HOTS mathematics problem. The lack of exercise in non-routine problems duringlearning is suspected to be the trigger. As mentioned earlier by Dewantara, Zulkardi \& Darmawijoyo (2015), Kusaeri, Sadieda, Indayati, \& Faizien (2018), as well as Sembiring, Hadi, \& Dolk (2008), problems presented during learning in classroom by mathematics teacher commonly demand more of student's ability to apply formulas, procedures or algorithms.

From the descriptionabove, it can be concluded that the stimuli of HOTs type mathematics test with Islamic context make most of the students more confused, because they experience difficulty in connecting information in the problem. Lack of exercise during learning and long narration brings difficultiesto the students.

\section{CONCLUSION}

Findings from this research show that most of students are 'less ready' to face HOTs type mathematics test because of lack of experience in dealing with this kind of questions. They expect to be trained and get accustomed to interacting with HOTs type mathematics test. Less readiness in facing non-routine problems, too long narration, laziness and less familiarity with Islamic terms are difficulties faced by students in completing HOTs type mathematics test. These findings suggest the importance of changing the way teachers assign exercises, assignments and exams, to not only take routine questions from the textbooks that require only a low-level thinking.

This highlights the need for mathematics teachers to provide students with experience to practice and interact with HOTs type mathematics problem in their day to day mathematics learning not only in class but also at home as homework and in the formative and summative assessment. For teachers in Islamic schools and madrasah tsanawiyah, the HOTs type of mathematics problem should not be too long in order to avoid student confusion and demotivation to read the questions.

This study only collected data on the student challenges from the result of multiple choice test and questionnaire. Although these data collection techniques can be considered as appropriate and sufficient, further research using interview as a triangulation is worth doing to provide more robust and comprehensive data. 


\section{ACKNOWLEDGMENTS}

This article is part of a research funded by Institute for Research and Community Service (LPPM) UIN Sunan Ampel Surabaya, based on the Rector Decree No. 187, 2018, April 19, 2018. Therefore, a thank note goes to the Chair of UIN Sunan LPPM Ampel Surabaya. The researcher would like to thank principles of the schools and teachers involved in the research (particularly Elmita Irmanila and M. Ikmal Faizien). May Allah grant them with the best award.

\section{REFERENCES}

Abdullah, A. H., Abidin, N. L. Z., \& Ali, M. (2015). Analysis of students' errors in solving Higher Order Thinking Skills (HOTS) problems for the topic of fraction. Asian Social Science, 11(21), 133.

Adeyemi, S. B. (2012). Developing Critical Thinking Skills in Students: A Mandate for Higher Education in Nigeria. European Journal of Educational Research, 1(2), 155-161.

Baker, F. B. (2001). The basics of item response theory. For full text: http://ericae. net/irt/baker..

Bokosmaty, S., Sweller, J., \& Kalyuga, S. (2015). Learning geometry problem solving by studying worked examples: Effects of learner guidance and expertise. American Educational Research Journal, 52(2), 307-333.

Dewantara, A. H., Zulkardi, Z., \& Darmawijoyo, D. (2015). Assessing seventh graders'mathematical literacy in solving pisa-like tasks. Journal on Mathematics Education, 6(2), 117-128.

Dorr, A. (2017). Common errors in reasoning about the future: Three informal fallacies. Technological Forecasting and Social Change, 116, 322-330.

Gais, Z., \& Afriansyah, E. A. (2017). Analisis kemampuan siswa dalam menyelesaikan soal high order thinking ditinjau dari kemampuan awal matematis siswa. Mosharafa: Jurnal Pendidikan Matematika, 6(2), 255-266.

Hadi, S., Retnawati, H., Munadi, S., Apino, E., \& Wulandari, N. F. (2018). The difficulties of high school students in solving higher-order thinking skills problems. Problems of Education in the 21st Century, 76(4).

Kamarullah, K. (2017). Pendidikan matematika di sekolah kita. Al Khawarizmi: Jurnal Pendidikan dan Pembelajaran Matematika, 1(1), 21-32.

Kurniati, A. (2015). Mengenalkan matematika terintegrasi islam kepada anak sejak dini. Suska Journal of Mathematics Education, 1(1), 1-8.

Kurniati, D., Harimukti, R., \& Jamil, N. A. (2016). Kemampuan berpikir tingkat tinggi siswa SMP di Kabupaten Jember dalam menyelesaikan soal berstandar PISA. Jurnal Penelitian dan Evaluasi Pendidikan, 20(2), 142-155.

Kusaeri, K. (2014). Acuan dan tehnik penilaian proses dan hasil belajar dalam kurikulum 2013. Yogyakarta: Ar-Ruzz Media.

Kusaeri, K., Sadieda, L. U., Indayati, T., \& Faizien, M. I. (2018). Developing an Assessment Instrument of Higher Order Thinking Skills in Mathematics with in 
Islamic Context. In Journal of Physics: Conference Series (Vol. 1097, No. 1, p. 012151). IOP Publishing.

Kusaeri, K., Aditomo, A., Ridho, A., \& Fuad, A. Z. (2018). Socioeconomic Status, Parental Involvement in Learning and Student'Mathematics Achievement in Indonesian Senior High School. Cakrawala Pendidikan. XXXVII(3), 333-344.

Kusaeri, K., \& Aditomo, A. (2019). Pedagogical Beliefs about Critical Thinking among Indonesian Mathematics Pre-service Teachers. International Journal of Instruction, 12(1).

Laily, I. F. (2014). Hubungan Kemampuan Membaca Pemahaman dengan Kemampuan Memahami Soal Cerita Matematika Sekolah Dasar. Eduma: Mathematics Education Learning and Teaching, 3(1).

Lee, M. Y., \& Francis, D. C. (2018). Investigating the relationships among elementary teachers' perceptions of the use of students' thinking, their professional noticing skills, and their teaching practices. The Journal of Mathematical Behavior, 51, 118128.

Marin, L. M., \& Halpern, D. F. (2011). Pedagogy for developing critical thinking in adolescents: Explicit instruction produces greatest gains. Thinking Skills and Creativity, 6(1), 1-13.

Muis, K. R., Psaradellis, C., Lajoie, S. P., Di Leo, I., \& Chevrier, M. (2015). The role of epistemic emotions in mathematics problem solving. Contemporary Educational Psychology, 42, 172-185.

Nadapdap, A. T. Y., \& Istiyono, E. (2017). Developing physics problem-solving skill test for grade $\mathrm{X}$ students of senior high school. REiD (Research and Evaluation in Education), 3(2), 114-123.

Nursyahidah, F., \& Albab, I. U. (2017). Investigating student difficulties on integral calculus based on critical thinking aspects. Jurnal Riset Pendidikan Matematika, 4(2), 211-218.

Samritin, S., \& Suryanto, S. (2016). Developing an assessment instrument of junior high school students' higher order thinking skills in mathematics. REiD (Research and Evaluation in Education), 2(1), 92-107.

Sembiring, R. K., Hadi, S., \& Dolk, M. (2008). Reforming mathematics learning in Indonesian classrooms through RME. ZDM, 40(6), 927-939.

Suryapuspitarini, B. K., Wardono, W., \& Kartono, K. (2018). Analisis Soal-Soal Matematika Tipe Higher Order Thinking Skill (HOTS) pada Kurikulum 2013 untuk Mendukung Kemampuan Literasi Siswa. In PRISMA, Prosiding Seminar Nasional Matematika, 1, 876-884.

Taleb, H. \& Chadwick, C. (2016). Enhancing students analitycal critical thinking skills and thinking skills at the higher education level in developing countries: a case study in Dubai. Journal of Education and Instructional Studies in the World, 6(1), 67-76.

Treagust, D. (2006). Conceptual Change as a Viable Approach to Understanding Student Learning in Science. In Teaching and Learning Science-A Handbook (pp. 25-32). Praeger Publications. 
